\title{
Effect of Heat Treatment on Structural and Mechanical Properties of Alloyed Fused Alumina
}

\author{
Yu. Bagaiskov ${ }^{1, a^{*}}$ and N. Ushakov ${ }^{1, b}$ \\ ${ }^{1}$ Volzhsky Polytechnic Institute (branch) of the Volgograd State Technical University, 43a \\ Engelsast., Volzhsky, Volgograd Region, 404130, Russia \\ a bagaiskov@post.volpi.ru, bushakov@post.volpi.ru
}

Keywords: Fused Alumina, Alloying, Heat Treatment, Structure, Strength

\begin{abstract}
Heat treatment of ceramic-bond grinding tools during manufacture takes place at temperature of abrasive grains up to $1250{ }^{\circ} \mathrm{C}$, which results in variation of their phase composition, structure, and strength. Similar phenomena may take place during grinding caused by the occurring high-temperature processes. It primarily pertains to alloyed fused alumina. X-ray and topography testing, as well as studying of micromechanical properties made it clear that structural performance, material strength, and fracture pattern of single grains of Ti-containing fused alumina affected by temperature depend on the type and ratio of alloy additives in alumina and on the decomposition level of the $\mathrm{Ti}_{2} \mathrm{O}_{3}$ solid solution. In terms of aggregate properties, purple varieties of $\mathrm{Cr}$-Ti fused alumina featuring the minimum $\mathrm{TiO}_{2} / \mathrm{Cr}_{2} \mathrm{O}_{3}$ ratio of 1.5 in the solid solution after heat treatment are preferable.
\end{abstract}

\section{Introduction}

In the course of manufacturing ceramic-bond grinding tools, abrasive-material grains are heated up to $1250^{\circ} \mathrm{C}$ [1], which unavoidably results in variation of their phase composition, structure, and, subsequently, structural-mechanical properties. In operation, similar phenomena may take place during grinding caused by the occurring high-temperature processes [2].

It is understood that high-temperature heating of Ti-bearing fused alumina results in breakdowns of the $\mathrm{Ti}_{2} \mathrm{O}_{3}$ solid solution [3]. It is assumed to be a relationship between breakdown of the solid Ti solution in alumina and the structural-mechanical properties of alloyed fused alumina [4].

Studies were conducted, using $400-\mu \mathrm{m}$ isometric-shape clear transparent alumina grains sampled from industrial batches of $\mathrm{Cr}-\mathrm{Ti}, \mathrm{Ti}, \mathrm{Cr}$, and white fused alumina. A binocular stereoscopic microscope was applied to select grains homogeneous in color: brown ( $\mathrm{Ti}$ and $\mathrm{Cr}-\mathrm{Ti}$ fused alumina), purple (Cr-Ti fused alumina), crimson ( $\mathrm{Cr}$ fused alumina), colorless (white fused alumina) $[1,5,6]$. Such sampling minimized the influence of the grain size and shape and inclusions of associated phases on the grain physical and mechanical properties.

Breakdown of the solid $\mathrm{Ti}_{2} \mathrm{O}_{3}$ solution was achieved by baking the sampled grains in a siliconcarbide kiln within the range of $1150-1350{ }^{\circ} \mathrm{C}$ for 2 hours. The breakdown level of the solid solution depended on the heat-treatment temperature and duration.

The chemical composition of the initial (before heat treatment) fused alumina in terms of alloying oxides is given in Table 1, their structural condition - in Table 2. Purple and brown grains selected from the same batch of Cr-Ti fused alumina (samples 5-1 and 5-2) feature different ratios of $\mathrm{Ti}$ and $\mathrm{Cr}$ oxides in the $\mathrm{Ti}_{2} \mathrm{O}_{3} / \mathrm{Cr}_{2} \mathrm{O}_{3}$ solid solution $\leq 1.5$ (this figure has been confirmed by analyzing more than 50 samples obtained in the course of studying $\mathrm{Cr}$ - $\mathrm{Ti}$ fused alumina at different times). The spectral method was applied to determine the content of $\mathrm{Cr}_{2} \mathrm{O}_{3}$ and $\mathrm{TiO}_{2}$. The 
solid solution of alumina contains $\mathrm{Ti}^{3+}$ ions, so the spectral analysis data were recalculated in terms of $\mathrm{TiO}_{2}[3]$.

Table 1. Chemical composition of initial alumina

\begin{tabular}{|c|l|l|c|c|c|c|}
\hline \multirow{2}{*}{$\begin{array}{c}\text { Sample } \\
\text { No. }\end{array}$} & \multirow{2}{*}{$\begin{array}{c}\text { Type } \\
\text { of fused alumina }\end{array}$} & \multirow{2}{*}{ Color } & \multicolumn{4}{|c|}{ Mass content (\%) } \\
\cline { 4 - 7 } & & \multicolumn{2}{|c|}{$\mathrm{TiO}_{2}$} & \multicolumn{2}{c|}{$\mathrm{Cr}_{2} \mathrm{O}_{3}$} \\
\cline { 3 - 7 } & & Initial & $\begin{array}{c}\text { Solid } \\
\text { solution }\end{array}$ & Initial & $\begin{array}{c}\text { Solid } \\
\text { solution }\end{array}$ \\
\hline 1 & $\begin{array}{l}\text { White fused } \\
\text { alumina }\end{array}$ & Colorless & - & - & - & - \\
\hline 2 & Ti fused alumina & Brown & 0.34 & 0.73 & - & - \\
\hline 3 & Cr fused alumina & Crimson & - & - & 0.65 & 0.50 \\
\hline 4 & $\begin{array}{l}\text { Cr-Ti fused } \\
\text { alumina }\end{array}$ & Brown & 0.75 & 0.64 & 0.26 & 0.23 \\
\hline $5-1$ & $\begin{array}{l}\text { Cr-Ti fused } \\
\text { alumina }\end{array}$ & Brown & 1.06 & 0.98 & 0.40 & 0.28 \\
\hline $5-2$ & $\begin{array}{l}\text { Cr-Ti fused } \\
\text { alumina }\end{array}$ & Purple & 0.83 & 0.51 & 0.38 & 0.33 \\
\hline 6 & $\begin{array}{l}\text { Cr-Ti fused } \\
\text { alumina }\end{array}$ & Purple & 0.83 & 0.49 & 0.66 & 0.62 \\
\hline
\end{tabular}

\section{Study results}

The Laue X-ray and topography methods were applied to study the structural condition of singlecrystal grains of alloyed alumina prior to and after high-temperature heating; besides, the powder method was applied to determine the structural parameters of the lattice (interplanar spacing $\mathrm{d}_{41.6}$ and the value of micro strain $\varepsilon$ ) of alloyed alumina (Table 2). The table comprise the structural analysis data of alloyed fused alumina after heat treatment at $1250{ }^{\circ} \mathrm{C}$ and $1350{ }^{\circ} \mathrm{C}$ as compared to the initial condition [4]. The single-crystal grains of white and $\mathrm{Cr}$ fused alumina are close in terms of the substructure and feature a Laue diffraction pattern with single spots inherent in perfect mosaic crystals. The substructure of Ti-bearing fused alumina ( $\mathrm{Cr}-\mathrm{Ti}$ and $\mathrm{Ti}$ fused alumina) has no significant difference. According to the Laue diffraction pattern, the single-crystal grains of such fused alumina feature a mosaic block structure; the topograms feature inhomogeneous intensity contrast typical for non-uniform distribution of the defects that form strain centers within the grain volume. The contrast pattern obtained in the topograms is associated with piling-up of dislocations caused by non-uniform distribution of the $\mathrm{Ti}_{2} \mathrm{O}_{3}$ and $\mathrm{Cr}_{2} \mathrm{O}_{3}$ solid solutions in a crystal and segregation of the mixture of the alloying agents that failed to completely penetrate into the solid solution. Besides, dislocation density $\rho$ is significantly higher than that of white and $\mathrm{Cr}$ fused alumina. Thus, Ti affects straining distortion of the alumina lattice to a higher extent as compared to $\mathrm{Cr}$. 
Table 2. Alloyed alumina structure prior to and after heat treatment

\begin{tabular}{|c|c|c|c|c|c|c|c|c|}
\hline \multicolumn{4}{|c|}{ Initial } & \multicolumn{3}{|c|}{$1250^{\circ} \mathrm{C}$} & \multicolumn{2}{|c|}{$1350^{\circ} \mathrm{C}$} \\
\hline \multicolumn{2}{|c|}{$d_{41,6} \cdot \stackrel{0}{(A)}$} & $\varepsilon \cdot\left(10^{4}\right.$ & $\rho,\left(c M^{-2}\right.$ & $d_{41,6} \cdot(\stackrel{0}{A})$ & $\varepsilon \cdot\left(10^{4}\right)$ & $\rho,\left(c M^{-2}\right)$ & $\left.d_{41,6} \cdot \stackrel{0}{A}\right)$ & $\varepsilon \cdot\left(10^{4}\right)$ \\
\hline $\begin{array}{l}\text { 1. White fused } \\
\text { alumina }\end{array}$ & 0.83057 & 3 & $5 \cdot 10^{6}$ & 0.83057 & 3 & - & - & - \\
\hline $\begin{array}{l}2 . \quad \mathrm{Ti} \text { fused } \\
\text { alumina }\end{array}$ & 0.83086 & 8 & $7 \cdot 10^{7}$ & 0.83072 & 6 & $9 \cdot 10^{7}$ & 0.83056 & 3 \\
\hline $\begin{array}{l}\text { 3. } \mathrm{Cr} \text { fused } \\
\text { alumina }\end{array}$ & 0.83069 & 8 & $5 \cdot 10^{6}$ & 0.83060 & 5 & - & 0.83072 & 5 \\
\hline $\begin{array}{l}\text { 4. Cr-Ti fused } \\
\text { alumina }\end{array}$ & 0.83111 & 9 & $7 \cdot 10^{7}$ & 0.83081 & 6 & $15 \cdot 10^{7}$ & 0.83093 & 7 \\
\hline $\begin{array}{l}5-1 . \text { Cr-Ti fused } \\
\text { alumina }\end{array}$ & 0.83086 & 8 & $5 \cdot 10^{7}$ & 0.83080 & 6 & $15 \cdot 10^{7}$ & 0.83069 & 5 \\
\hline $\begin{array}{l}5-2 . \text { Cr-Ti fused } \\
\text { alumina }\end{array}$ & 0.83085 & 5 & $5 \cdot 10^{7}$ & 0.83075 & 6 & $15 \cdot 10^{7}$ & 0.83080 & 5 \\
\hline $\begin{array}{l}\text { 6. Cr-Ti fused } \\
\text { alumina }\end{array}$ & 0.83103 & 6 & $6 \cdot 10^{7}$ & 0.83081 & 6 & $15 \cdot 10^{7}$ & 0.83074 & 6 \\
\hline
\end{tabular}

Alumina changes its color in the course of heat treatment in air within the temperature range of $1150-1350{ }^{\circ} \mathrm{C}$. The $\mathrm{Ti}$ alumina color (sample 2) changes most abruptly: initially brown grains become milky-blue/milky-white after heating up to $1350{ }^{\circ} \mathrm{C}$. Brown grains of Cr-Ti fused alumina (samples 4 and 5-1) become milky-pink/milky-blue; purple grains of Cr-Ti fused alumina (samples 5-2 and 6) lose transparency. Cr fused alumina (sample 3) retains its color after heat treatment and remains crimson, yet the color becomes more intensive. In Ti-bearing fused alumina, color changing is accompanied by inclusions of a new phase - $\mathrm{TiO}_{2}$ rutile - and caused by breakdown of the $\mathrm{Ti}^{3+}$ solid solution in $\mathrm{Al}_{2} \mathrm{O}_{3}$ and $\mathrm{Ti}^{3+}$ oxidation to $\mathrm{Ti}^{4+}$. The early breakdown stage of the $\mathrm{Ti}_{2} \mathrm{O}_{3}$ solid solution features occurrence of thin-plate formations that are structurally linked to the alumina matrix and cause diffused scattering in Laue diffraction patterns. Analysis of the diffused scattering pattern enabled calculating the thickness of bidimensional formations equal $\sim 50-100$ A. As the heating temperature rises, the thin-plate formations grow and turn into rutile pins consistently located in alumina crystals.

Breakdown of the $\mathrm{Ti}_{2} \mathrm{O}_{3}$ solid solution with the release of rutile results in variation of the alumina chemical composition: the content of $\mathrm{Ti}_{2} \mathrm{O}_{3}$ in the solid solution gradually decreases as the heating temperature rises (by 20-35\% after heating up to $1350{ }^{\circ} \mathrm{C}$ ); the content of $\mathrm{Cr}_{2} \mathrm{O}_{3}$ in the solid solution remains nearly the same.

Breakdown of the $\mathrm{Ti}_{2} \mathrm{O}_{3}$ solid solution in purple grains of $\mathrm{Cr}$ - $\mathrm{Ti}$ fused alumina takes place within the range of higher temperature values, approximately by $100{ }^{\circ} \mathrm{C}$. This is due to the fact that alumina with higher content of $\mathrm{Cr}_{2} \mathrm{O}_{3}$ in the structure is nearly always saturated with beads of the Cr-bearing alloy resulted from reduction of chromium oxide during melting. Metallic $\mathrm{Cr}$ oxidizes during alumina heat treatment (besides, the $\mathrm{Cr}$ content in the solid solution increases); oxidizing $\mathrm{Cr}$ creates oxygen deficit and thus prevents transfer of trivalent $\mathrm{Ti}$ into tetravalent. 
Heating of alloyed alumina is accompanied by monotonous decrease of the parameters and a reduced micro strain level of the lattice. As the heating temperature increases up to $1350{ }^{\circ} \mathrm{C}$, the parameters of interplanar spacing $\mathrm{d}_{41.6}$ and micro strain value $\varepsilon$ of $\mathrm{Ti}$ alumina approximate such parameters of white alumina; in $\mathrm{Cr}-\mathrm{Ti}$ alumina, the parameters decrease to a lesser degree; as for Cr alumina, parameter $d_{41,6}$ even increases in a measure.

Superfine rutile inclusions regularly oriented in related to the matrix and resulted from breakdown of the $\mathrm{Ti}_{2} \mathrm{O}_{3}$ solid solution do not cause strain distortions of alumina, which is confirmed by the obtained Laue diffraction patterns and topograms.

Elastic stresses release at the inclusion-matrix/rutile-alumina interface due to formation of a dislocation structure eliminating lattice misfit between the inclusions and matrix and thus reducing elastic distortions. According to the contrast pattern in the topograms, heating of Ti fused alumina results in a more balanced lattice condition and stress relief $[3,4]$.

Relation between the $\mathrm{TiO}_{2}$ content in the solid solution of alumina and the heating temperature is shown in Fig. 1.

After heating at $1150-1350{ }^{\circ} \mathrm{C}$, the substructure of $\mathrm{Cr}$ alumina grains (sample 3 ) is not so different from that of initial grains: the topograms feature inhomogeneous intensity contrast typical for non-uniform distribution of defects (strain centers) within the grain volume.

Cr-Ti fused alumina (samples 4, 5, and 6) after high-temperature heating behaves variously, depending on the $\mathrm{Ti}^{3+}$ content in the solid solution: the structure of brown grains (the ratio in the $\mathrm{TiO}_{2} / \mathrm{Cr}_{2} \mathrm{O}_{3}$ solid solution $\geq 1.5$ ) becomes more balanced; as for purple grains $\left(\mathrm{TiO}_{2} / \mathrm{Cr}_{2} \mathrm{O}_{3} \leq 1.5\right)$, defects are distributed non-uniformly, so the structure remains unbalanced similarly to $\mathrm{Cr}$ alumina.

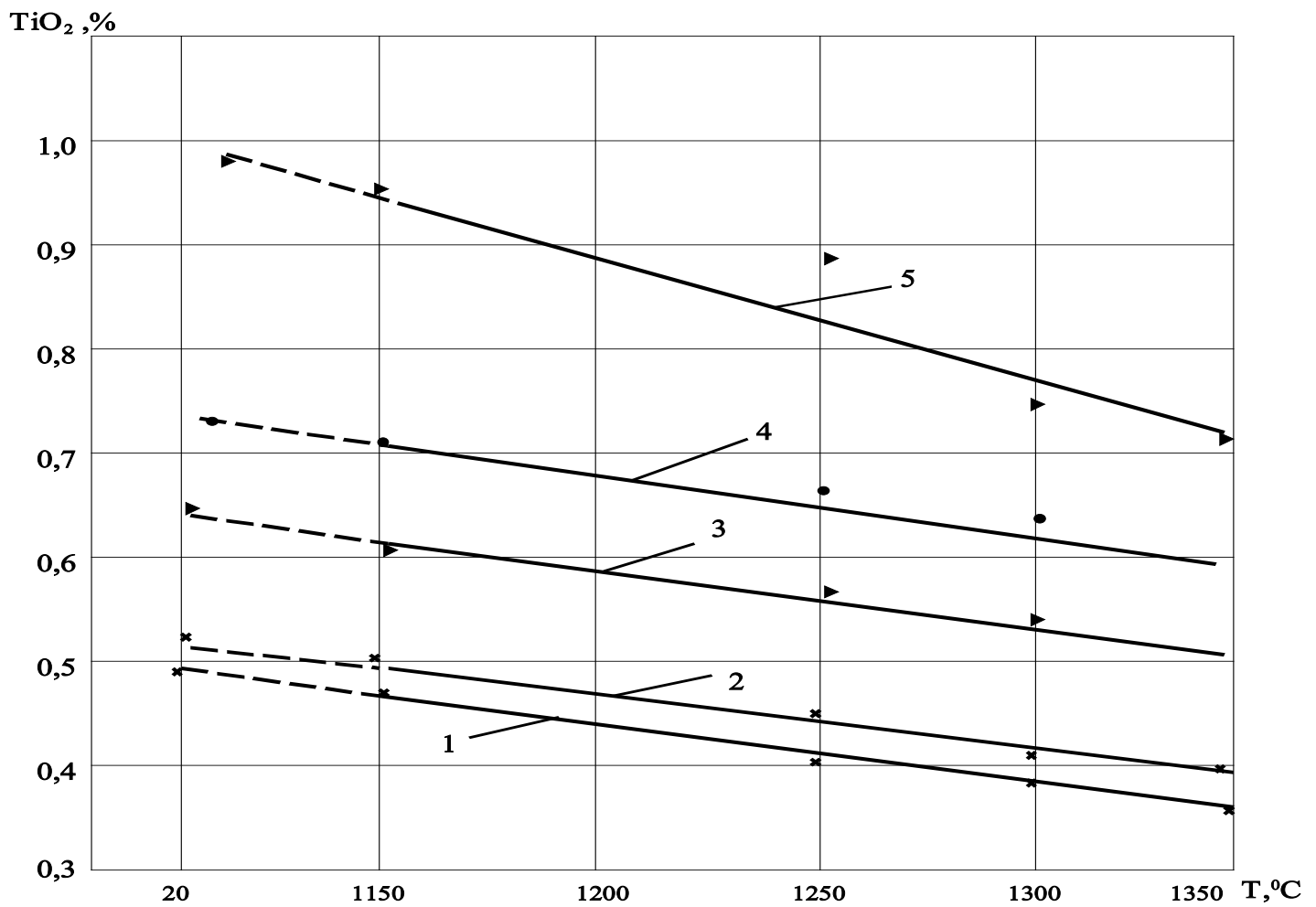

Fig. 1. Relation between $\mathrm{Ti}^{3+}$ content in the solid solution of alumina (in terms of $\mathrm{TiO}_{2}$ ) and heating temperature T: 1 - sample 6; 2 - sample 5-2; 3 - sample 4; 4 - sample $2 ; 5$ sample 5-1 
The study revealed higher values of Cr-Ti fused alumina micromechanical parameters $[4,7,8$, 9], besides, purple grains have the maximum values; such $\mathrm{Cr}-\mathrm{Ti}$ fused alumina reaches the maximum values of micro hardness and crack resistance after heat treatment at $1250{ }^{\circ} \mathrm{C}$.

The wear resistance study [10] under micro cutting conditions made it clear that the wear resistance of all initial fused alumina involving macro shears (cutting depth, depth of the last notch before shearing) is nearly the same and fluctuates within $15-17 \mu \mathrm{m}$; after heating at $1250{ }^{\circ} \mathrm{C}$, it remains at the previous level for white fused alumina and increases up to $20 \mu \mathrm{m}$ for $\mathrm{Ti}$ and $\mathrm{Cr}-\mathrm{Ti}$ fused alumina. This parameter describes structural performance of materials (the stronger the material the deeper the notch).

\section{Conclusion}

Thus, the conducted study made it clear that structural performance, material strength, and fracture pattern of single grains of Ti-containing fused alumina depend on the type and ratio of alloy additives in alumina and on the decomposition level of the $\mathrm{Ti}_{2} \mathrm{O}_{3}$ solid solution resulting from grain heat-treatment in open air. Purple varieties of $\mathrm{Cr}$-Ti fused alumina featuring the minimum $\mathrm{TiO}^{2} / \mathrm{Cr}_{2} \mathrm{O}_{3}$ ratio of 1.5 in the solid solution after heat treatment at $1250{ }^{\circ} \mathrm{C}$ are preferable.

\section{References}

[1] A. Garshin, S. Fedotova, Abrasive Materials and Tools. Manufacturing Procedure: Instructional, Aid, SPb.: Polytechnic University Press, 2008.

[2] V. Ostrovsky, Theoretical Basis of Grinding, Leningrad: Leningrad State University Press, 1981.

[3] I. Lavrov, I. Rivlin and T. Nikitina, Physical and Chemical Studies of Abrasive Materials and Tools, Collected Papers, L.: VNIIASh, 1981, pp $69-75$.

[4] O. Pushkarev, V. Schumyacher, Methods and Equipment for Monitoring of Abrasive Materials' Physical and Mechanical Characteristics: Monograph, Volgograd: VolgGASU, 2004.

[5] E. Gevorkyan, Super Hard Materials. 5 (2004) 54-57.

[6] A. Ovchinnikov, Materials for Abrasive Tools. Review Science and Education, 7, 2013. https://doi.org/10.7463/0713.0577449

[7] V. Berdikov, A. Diulin, V. Efimchuk, O. Pushkarev and G. Finogenov, Device for Studying Durability of Materials, Plant Laboratory. 7 (1986) 78 - 81

[8] O. Pushkarev, Yu. Bagaiskov, Investigation of micromechanical properties of fused alumina and silicone carbide grains, Journal of Physics: Conference Series. 2020. - Vol. 1515 : International Scientific Conf. «Metrological Support of Innovative Technologies - ICMSIT2020» (Krasnoyarsk, Russia, 4 March, 2020). https://doi.org/10.1088/1742-6596/1515/5/052016

[9] O. Pushkarev, O. Kulik and L. Nikuiko, Plant Laboratory. Material Diagnostics. 83 (2017) 49-52.

[10] O. Pushkarev, Yu. Bagaiskov, Refinement of the procedure to determine durability of abrasive materials, IOP Conference Series: Materials Science and Engineering. Vol. 862 : II International Conference «MIP: Engineering-2020: Modernization, Innovations, Progress: Advanced Technologies in Material Science, Mechanical and Automation Engineering» (Krasnoyarsk, Russia, 16-18 April, 2020). https://doi.org/10.1088/1757-899X/862/3/032019 